\title{
Global Arabic Studies: Lessons from a Transnational Asian Heritage. (中
} 文)

Edition 2, 2020

Tarek Makhlouf

DOI: 10.37839/MAR2652-550X2.14

\section{中文 (Chinese translation)}

Sometime in early 2010 I was visiting my favourite bookshops in the al-Halbouni suburb of Damascus. Al-Halbouni is an Arabic bibliophile's paradise: it has dozens of bookshops door-to-door packed with books of all genres and types. Closely scanning the shelf before me, my hand went instantly for a volume with a blank spine, a good sign that it was a facsimile of a rare text printed in the late nineteenth or early twentieth centuries. My intuition did not fail me: I had stumbled on a commentary of a classical Arabic philosophical text that was new to me. But my excitement was soon replaced by astonishment as my eyes went down the page. I stopped and stared at the two lines of Cyrillic text. The accompanying Arabic told me that this book was printed in 1901 in Kazan, in what was then the Russian Empire. I had seen texts printed in many places before; from Leipzig to Lucknow and many others in between. But this book elicited new emotions and thoughts. I felt like I had discovered a new planet, a new world yet unexplored-which prompted a question: is Arabic studies generally taught too narrowly?

\section{Reconfiguring Arabic Studies in Australia}

Today, Arabic is mostly thought of as the language of the Arab world and the liturgical language of Islam. Arabic, and its literary heritage, is much more than a 
national or religious language: it is a classical and global cosmopolitan language with a vibrant culture that spans a millennium. It is a language that gives access to a treasure-trove of literature, culture, and philosophical learning. From Nanjing to Lisbon, Kazan to Cape Town, and Manila to Edinburgh, the Arabic language and its modes of thought continue to shape the world as we know it today. The wide geographic spread of Arabic and its complex interactions with different Asian cultures challenge us to think of Arabic studies differently. To think of Arabic's many engagements and interconnections beyond the Arab world is to engage in an interdisciplinary and transnational study of much of Afro-Eurasia.

In the following lines, I'll trace how Arabic spread over Asia. Similar or longer articles can be written for each of Africa and Europe. While each brief account could itself be the basis of a lengthy study, my purpose here is to speak to the significance of the sum total of these accounts. The bottom line is that Arabic has significantly influenced, and continues to influence, Asia; and Arabic culture forms the substratum of a large part of South-East Asian and South Asian culture. Arabic and Asian studies programs should be redesigned to make this cultural sphere more accessible to a new generation of students.

\section{The Beginning of Arabic}

Arabic began as the language of the inhabitants of the northern part of the Arabian Peninsula at least two thousand years ago. The Arabs were politically insignificant on the world stage and therefore there was not much interest in their language. Some Arabs were sedentary and others semi-nomadic. The western region along the Red Sea (the Hijaz) was on an ancient trade route between India (via Yemen) and Damascus. The Arabs prided themselves on their poetry. They used poetry to speak of love and betrayal and to call their tribe to arms or lampoon their enemies.

Islam forever changed the fate of Arabic, transforming it from the language of a people to the language of a religion and many empires. In 610 in the city of Mecca, 
the Arabian hub of the Hijaz trade route, the Prophet Muhammad began receiving a revelation from Allah known as the Qur'an. The message of the Qur'an was to shun idolatry and adhere to monotheism, and that Muhammad was the last in the line of series of prophets sent by God to guide humanity. The Qur'an was regarded as the verbatim word of God, and this religious weight was the historical foundation of Arabic's power.

\section{The Early Expansion of Arabic}

A series of socio-political events ensured that Arabic would not be confined to a ritualistic language of scripture. The Arabic language's ascendancy was buttressed by three developments that occurred mainly in the eighth century: the explication of Arabic's grammar and refinement of its orthography, the use of Arabic as an imperial language, and the adoption of a new technology: paper.

The initial impetus for the development of Arabic grammar was the worry that Arabic would be lost. After the Prophet Muhammad's death in 632 the Arabs increasingly lived in multi-lingual societies. All languages change with time, a process probably accelerated by contact with new languages. The Prophet's companions perceived a change in their own language and within decades after his death they began a concerted effort to preserve the type of Arabic that was in the idiom of the Qur'an. The poetry of the Arabs was recorded, and data was elicited from native speakers. Furious debates about the validity of data and the methods of rule formation were part of a vibrant intellectual community. This linguistic work reached its apex in the grammatical treatise known simply as al-Kitab (literally 'the book') of Sibawayh (d. c. 796). The Kitab is a full explication of Arabic grammar, thoroughly referenced and replete with evidentiary quotes to substantiate its claims. In tandem with the need to preserve Arabic, the need to better understand the Qur'an motivated Muslims to closely scrutinise the mechanics of Arabic. More specifically, the Qur'an brought attention to its language by challenging the Arabs, a nation of poets, to match its eloquence. The need to understand the Qur'an's 
inimitability (a seemingly paradoxical quest) propelled scholars to make wonderful strides in the study of Arabic grammar, rhetoric, and literature. These works are still read and appreciated today, the contents of which are significant for world history, linguistics, and Islamic jurisprudence. During this time the Arabic script underwent a series of small yet significant changes. Different sounds using the same letter were differentiated by dots, short vowels were made explicit using small symbols, and spelling was standardised.

A second development occurred when Arabic assumed a political role. The Umayyad Caliph Abd al-Malik ibn Marwan (d. 705) decreed that Arabic would become the official language of the empire, replacing the other administrative languages: the Greek of the Byzantine Empire and Middle Persian of the Sassanid Empire. The use of Arabic in the bureaucracy meant that many scribes had to be trained, spawning a genre of writing manuals that uncannily resemble our own. Arabic also became publicly visible: it was minted on coins and inscribed on buildings.

A third development formed the backbone of Arabic's proliferation: Muslims imported the technique of paper-making from China. Prior to this the main materials used for writing were either papyrus or parchment. Papyrus, made by smashing the reeds of the papyrus plant together, was cheap to make, but not very durable. Parchment, created from the prepared skins of animals, was durable, but expensive. Paper, made then out of cotton or linen (and not wood), balanced cost with durability.

By the beginning of the ninth century Arabic was ready to be used widely: its grammar was sufficiently well documented and therefore could be learned, it was backed by an empire and a network of patrons, and could be distributed in a relatively cheap manner on paper. Arabic travelled wherever Muslims went-bringing with it its script and literary canon. It cruised around the Mediterranean, traversed the silk roads, sailed around the Indian Ocean and crossed the Sahara. 


\section{Arabic in the Arab World}

At the time of the death of the Prophet Muhammad, the Arabic language was only spoken in the northern part of the Arabian Peninsula and the Syrian desert. By the middle of the eighth century the Islamic empire had spread from the Iberian Peninsula (in modern day Spain) to the Sindh (in modern day Pakistan). While Islam was the religion of the governing class and Arabic the language of administration, Islam and Arabic were not immediately adopted by the population. It took several centuries before Arabic became the dominant language in southern Arabia, the Levant, Egypt and North Africa-regions that are today thought of as squarely within the Arab world. This Islamisation and Arabisation also occurred unevenly; rural areas took much longer to Arabise. Certainly, the draw to Arabic for any Muslim was inescapable; it was the only language that could assure spiritual and material benefits.

Different languages in the region had different fates. Arabic slowly eclipsed Syriac (a type of Aramaic) which was the dominant language before Islam in the Levant. Languages related to Syriac (known as neo-Aramaic) are still spoken in pockets in Syria and Iraq and the diasporas of these communities. Syriac is still the language of many eastern Churches. Arabic never became dominant in the Kurdish and Persian speaking areas, despite their proximity to the Arabian Peninsula, but Arabic did take hold throughout North Africa and even in al-Andalus (Islamic Spain and Portugal). More to the point, a handful of South Arabian languages are still spoken in the region between Yemen and Oman and pre-date Arabic's arrival in this region. Factors such as the immigration of Arabs, the lack of local patrons for non-Arabic languages, and attitudes towards the languages of conquerors all played a part in Arabisation.

In the ninth and tenth centuries many Muslims, mainly Persian, participated in the shu'ubiyya movement protesting the privileged position of Arabs within Muslim society. Arabs would inevitably have unequal power in a society that privileged 
Arabic for political power. The position of shu'ubiyya protesters was nuanced: Arabic was resisted as a marker of religious superiority and political hegemony, but welcomed as a language of religion, culture, and science. Counterintuitively, the shu'ubiyya movement, amongst other factors, inevitably lead to Arabic language and culture spreader farther and wider, a point to which I will return.

\section{Arabic Literary Culture}

By the ninth century the majority of those writing in Arabic were ethnically nonArab. Arabic became the new site of world culture. The Nestorian Christians translated Hellenistic learning to Arabic (mostly via Syriac translations): the great philosophers of Athens (especially Aristotle) and the learning of Alexandria: the medicine of Galen, the mathematics of Euclid, and the astronomy of Ptolemy. The Persians brought their Middle Persian learning which often contained Sanskrit knowledge. One of the earliest great works of Arabic prose was Kalila wa-Dimna, translated from Middle Persian by Ibn al-Muqaffa (d. 759) and ultimately came from the Sanskrit Panchatantra ('five treatises')-a book of animal fables to teach virtues. In the following centuries the cultural and scientific knowledge held in Greek, Coptic, Ge'ez, Persian, Sanskrit, and many other languages flooded into Arabic making it a truly cosmopolitan language-not to mention the sizable religious literature that was written as Arabic became the lingua franca of the Islamic world.

Each ethnic and religious group had a unique relationship with Arabic. For example, Syriac Christians wrote Arabic in the Syriac script which they called Garshuni, and the Jews wrote Arabic in the Hebrew script, today known as Judeo-Arabic. Any speaker of Arabic can read these texts today if they spend a few hours understanding how the Syriac and Hebrew scripts were employed in writing Arabic. Arabic was a melting pot of cultures and languages. It was the language everyone wanted to read and in which everyone wanted to be read. 


\section{Persian: A Model for Adopting and Adapting Arabic}

The tenth century ushered in a new literary renaissance for the Persian language. In the centuries following Islamic conquest in the seventh century, Arabic largely displaced Middle Persian (Pahlavi) as the literary language. The Abbasid Caliphate, centred in Baghdad, nominally ruled the whole Empire, but by the ninth century its various regions became essentially autonomous, effectively ruled by their governors. A number of these emirates in the western Iranian lands began to patronise Persian literary production in addition to their substantial patronage of Arabic science and literature. In this cosmopolitan milieu, the Persian literati fashioned a connoisseur's language: new Persian. New Persian was a mixture of various Middle Persian languages heavily infused with Arabic vocabulary and idioms. New Persian adopted the Arabic script, modifying several letters to accommodate sounds not in Arabic, giving birth to the Perso-Arabic script. A clear division of labour formed within these Persian dynasties of the tenth century: Arabic was largely used for scientific and religious purposes and Persian was the court language and the main language of literature. A key proponent of this new cultural model was the Samanid Empire, centred in Samarkand and later in Bukhara.

The Persian model of adopting and adapting Arabic idioms, motifs, vocabulary and script was a watershed moment. Firstly, it provided other languages with a model to localise Arabic language, literature, and script (such as Pashto, Uyghur, Turkic, Urdu and many others). Secondly, and more significantly, it became the prism through which the rest of mainland Asia experiences Arabic. This hybrid AraboPersian culture became the subsequent foundation of what is known as the Persianate world. This is a defining quality of the spread of Arabic culture throughout mainland Asia which contrasts with the spread of Arabic in Africa and southern Europe. 


\section{Central Asia and the Turco-Mongol World}

In between forging a new cultural formation, the Samanids found time to convert Turkic peoples in central Asia to Islam. By the end of the tenth century the Turkic Ghaznavids had overthrown the Samanids. Unbeknownst to them, the Samanids had set into motion a second socio-political force that would last a thousand years: the Turco-Mongol peoples became the major political force amongst Muslims in mainland Asia. While it was their military acumen that secured their political superiority, they became connoisseurs and patrons of the Arabo-Persian culture that they encountered. Turkic was added as a language for military and administrative matters, yielding a tripartite linguistic model that endured in certain places in Asia until the twentieth century. Today we associate Turkish with modern day Turkey, however the various Turkic peoples and their associated languages originate from central Asia. Needless to say, these Turkic languages were heavily influenced by Arabic and Persian. What followed was a series of Turkic and Mongol empires that spread Arabo-Persian culture from Eastern Europe to China and Korea. Some of the more famous ones include the Seljuks (eleventh-twelfth) the Ottomans (fourteenthtwentieth), the Il-Khanates (thirteenth-fourteenth centuries), and the Timurids (fourteenth-sixteenth). The spread of Islam in the tenth century through the Caucasus and up the Volga river to the Volga Tatars, a Turkic people, is another instance of this. In the late nineteenth and early twentieth centuries, Kazan became a publishing powerhouse, producing books in Arabic, Persian, and Turkic languages, demonstrating just how long the tripartite model endured.

The purpose of discussing the Persian and Turkic languages here is threefold. The first is that wherever Persian went, Arabic was present as scientific and religious language. In many of these regions around Asia today only Arabic remains (because it is the language of Islam and the lingua franca of Muslims). Secondly, given that nearly every author who wrote in Persian also knew Arabic, and that Persian is infused with Arabic words and ideas, places Persian squarely within the cultural influence of Arabic. Thirdly, and most importantly, we do not need to limit Arabic 
studies to regions or texts that are exclusively Arabic. Some of the most fruitful research is to trace the intermingling of literature and idioms and the shift between languages which created a kaleidoscope of cultures. This mixing and hybridisation of culture is the crux of the flow of Arabic throughout Asia.

\section{South Asia}

The region that today forms Pakistan and northern India came under the sway of Arabic and Persian culture from the eleventh century. The height of this hybrid culture was achieved under the Mughals, a Turkic people who had adopted the Persianate culture and who ruled the region from the sixteenth century. Persian remained the court language until the nineteenth century. The sixteenth century onwards saw the rise of Urdu, but that is another discussion all together. Acclaimed scholar of India, Richard M. Eaton, adeptly discusses some of these topics with incredible sensitivity in his recent book India in the Persianate Age: 1000-1765. Within the Mughal empire, Arabic remained a scientific and religious language. In the nineteenth century many Arabic and Persian texts were printed in India; in Calcutta, Lucknow, Delhi and other places-demonstrating the continued vitality and currency that these languages had. Of the languages and cultures influenced by Arabic and Persian in the south of India I would like to single out Arwi, a dialect of Tamil written in a Perso-Arabic script with loanwords from Arabic. Arwi was widely used by Muslims in the southern tip of India and Sri Lanka to write poetry and literature as well as for religious purposes.

\section{China}

By the eighth century Arab and Persian Muslim traders had started settling in China in larger numbers. The Mongols of the Yuan Dynasty in China (thirteenth-fourteenth centuries) were partial to Muslims and many central Asian scholars, fluent in Arabic and Persian, found their way into the Chinese court. In the fourteenth century Muslims in China had developed Xiao'erjing, a system of writing Sinitic languages in 
Arabic characters. This system is still used among Chinese Muslims today. Traditional Muslim scholars in China are trained in Arabic and Persian to access a range of classical texts. One of the most astonishing intellectual and literary projects in Islamic history is a collection of works known as the Han Kitab. The name of this body work is itself a symbol of a hybrid culture: 'Han' the Chinese word for Chinese, and 'Kitab', the Arabic word for book. The project began in the seventeenth century in the Qing dynasty when Wang Daiyu, a master of Arabic, Persian, and Chinese, studied Confucianism, Buddhism and Taoism intensively after having mastered the Islamic disciplines. Wang chose to use Chinese words instead of Arabic or Persian ones, giving his works a distinctive Chinese flavour.

\section{Southeast Asia}

Islam spread to Southeast Asia via South Asian and Yemeni contact. This direct link with the Arabian Peninsula has meant that unlike mainland Asia, Persianate culture is not prevalent in South East Asia. The Malay language was written in the Jawi script, the earliest surviving witness is the Terengganu Inscription Stone (Batu Bersurat Terengganu) dated to 1303. Jawi was used to write many other languages across Southeast Asia including Tausug in the Philippines. The Javanese, Madurese, and Sundanese languages were also on occasion written in an Arabic script known as Pegon. Ronit Ricci of the Australian National University gives a peak into this world in her book Islam Translated: Literature, conversion and the Arabic Cosmopolis of South and Southeast Asia.

\section{Towards Global Arabic Studies}

The Arabic book printed in Kazan that I found in Damascus was a catalyst for me to reconsider Arabic studies. The role of Arabic in Africa, Europe, and Asia and the role of Persian across Asia is established in the academic literature, but is not yet common knowledge in the wider academic community. Arabic is not a single star, but a constellation. The various modern nation states and borders might obscure the 
broader influence of Arabic, but we neglect these transcultural and intercultural aspects to our own detriment.

With this in mind, Arabic studies in Australia can be redesigned to study not just the Arabic world, but also the influence and perfusion of the Arabic language, culture, script, and literature through Asia. In this way Arabic studies can be truly transnational-tracing the complex interactions that the Arabic traditions had in different regions, and the dynamic exchange it had with other literary cultures such as Persian, Sanskrit, and Chinese.

The flux, confluence, and divergence of these cultures is politically and culturally significant to the fabric of the Asian society today. To think of Arabic studies this way is to make Arabic studies pluricentric. It does not privilege an assumed centre over areas that are presumed peripheral and it places hybridity and interaction centre-stage. Subjects that look at Arabic through the Silk road or Indian Ocean trade routes could help achieve this aim. Similarly, subjects that include Arabic texts, or texts influenced by the Arabic sphere, in Asia while studying the various cultural contexts of their production would be interesting and lively. Teaching Arabic studies in this way in our universities will certainly make Arabic studies more vibrant and relevant to students. It may even help us restore a way of thinking and being that we have lost in an age where we find ourselves oscillating between hypernationalism and hyper-globalisation.

The author would like to thank three anonymous reviewers for their suggestions. He has abstained from using diacritics to improve readability.

Image credit: pxfuel.com 